\title{
E-PAYMENT: INOVASI LAYANAN PENGHIMPUNAN DAN REDISTRIBUSI WAKAF UANG BERBASIS ONLINE DALAM PERCEPATAN PEMBANGUNAN EKONOMI INDONESIA
}

\author{
Izra Berakon, Agus Muhammad Irsad, Nuha Nabila Hanif, dan Hikmatul Fisa Yasinta \\ Fakultas Ekonomi dan Bisnis Islam UIN Sunan Kalijaga Yogyakarta
}

\begin{abstract}
Indonesia as a major Muslim population country, has a large potential of cash waqf. Indonesian Waqf Board (BWI) predicted the potential of cash waqf in Indonesia is Rp 20 trillion, but had not followed by the effective collection method, so that potential has not been able to develop optimally. On the other hand, technology grown rapidly, followed by the numberof internet users in Indonesia. Based on the data of the Association of Internet Service Providers Indonesia (APJII) shows that internet users in Indonesia by aged 20 years and plus, reached 119.2 million inhabitants. It allows the integration of the effective system of collecting waqf property. One of the effective collecting efforts done by the government is to establish a waqf bank which role as nadzir beside a liason between wakif with the waqf management institutions. The main duty of waqf management institution here is as nadzir who will manage cash waqf productively and fostering the communityso as toempower the economy. However, the current establishment of waqf bank is still in the process of finalization, so there is no core principle in collecting waqf. Therefore, the purpose of this research is to offer an electronic application of collecting and redistributing cash waqf by the internet networking and the development of the digital era. It concept called e-payment. It choosen an e-payment as the concept, which wakif must fill the balance of waqf bank account from commercial bank accounts owned by wakif. Then wakif choose waqf allocation with options that have been provided by waqf bank.The research method usedis descriptive analysis and conjoint analysis. The final implication by the innovation of the e-payment application is that the existing ease of waqf collection is expected to be effective and reach many people and able to increase the economy of Indonesian society.
\end{abstract}

Keywords:venture waqf bank, e-payment, cash waqf, productive waqf

\section{PENDAHULUAN}

\section{Latar Belakang}

Indonesia memiliki 261,1 juta jumlah penduduk dengan keberagaman suku, ras, agama dan budaya (Bank Dunia, Biro Sensus Amerika Serikat: 2016). Agama merupakan salah satu hal yang penting, mengingat agama menjadi poin pertama yang tertuang dalam dasar negara Indonesia, yaitu Pancasila. Sila pertama yang berbunyi "Ketuhanan Yang Maha Esa” mencerminkan bahwa Indonesia tidak membatasi masyarakatnya dalam memeluk agama.

Hak penduduk Indonesia untuk memeluk agama juga terdapat pada UUD 1945 pasal 28E ayat 1 yang menyatakan bahwa "setiap orang bebas memeluk agama dan beribadat menurut agamanya, memilih pendidikan dan pengajaran, memilih pekerjaan, memilih kewarganegaraan, memilih tempat tinggal di wilayah negara dan meninggalkannya, serta berhak kembali". Dari pasal tersebut, menjelaskan bahwa pemerintah memberikan keleluasaan dalam berbagai hal salah satunya adalah kebebasan dalam memeluk agama. Hal ini didukung dengan adanya penjelasan atas Penetapan Presiden No 1 Tahun 1965 Tentang Pencegahan Penyalahgunaan dan/ atau Penodaan Agama pasal 1, bahwa "Agama-agama yang dipeluk oleh penduduk di Indonesia ialah Islam, Kristen, Katolik, Hindu, Budha dan Khog Hu Cu (Confusius)". 
Kementrian Agama pada tahun 2013 melakuakan pendataan penduduk Indonesia berdasarkan agama. Data tersebut menjukkan bahwa sebesar 87,21\% penduduk Indonesia beragama Islam, sebesar $6,96 \%$ beragama Kristen, sebesar $2.91 \%$ beragama Katolik, sebesar 1,69\% beragama Hindu , 0,72\% beragama Budha, sedangkan $0.05 \%$ beragama Konghuchu, dan $0.50 \%$ beragama lain-lain. Hal ini berarti bahwa mayoritas penduduk Indonesia beragama Islam. Data tersebut tersaji dalam diagram di bawah ini.

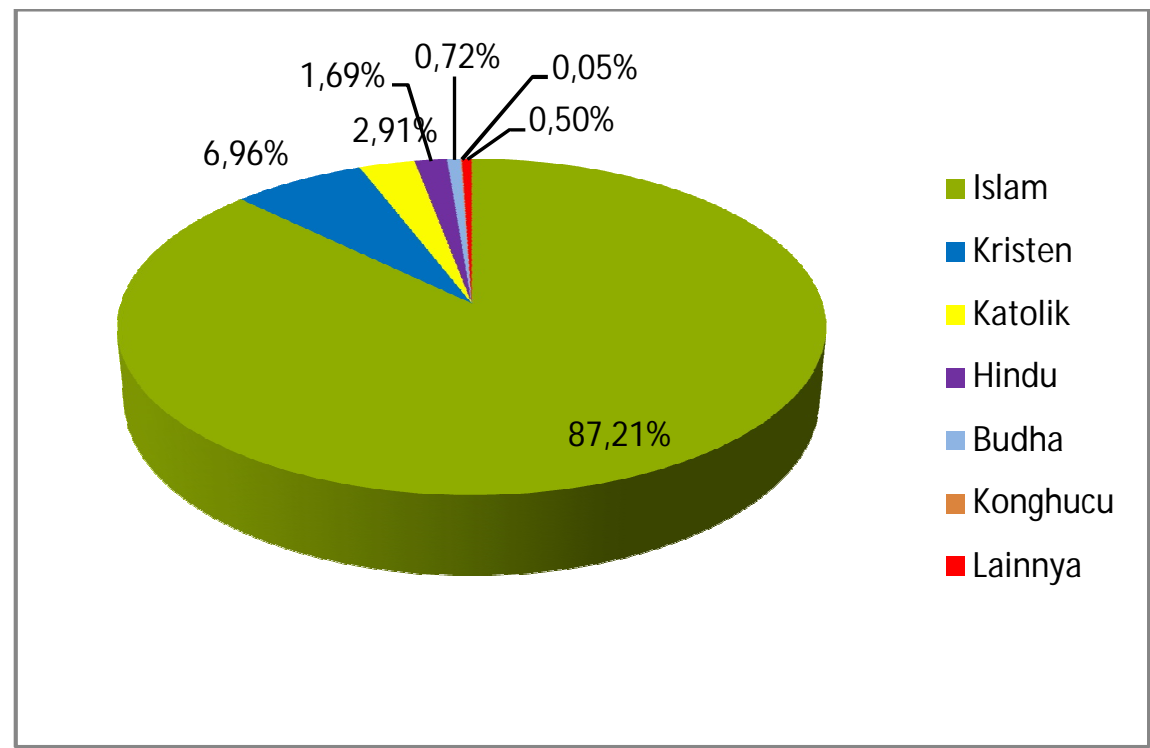

\section{Diagram 1. Presentase Penduduk Indonesia Menurut Agama Sumber: Kemenag, 2013 (Data diolah kembali)}

Indonesia yang mayoritas penduduknya beragama Islam mempengaruhi sistem yang berlaku dalam Negara Kesatuan Republik Indonesia, salah satunya adalah sistem perekonomian Indonesia. Sistem perekonomian Indonesia tidak terlepas dari sistem ekonomi Islam yang di dalamnya terdapat instrumen keuangan publik Islam, salah satunya adalah wakaf uang.

Wakaf uang dipandang sangat potensial dalam menciptakan kesejahteraan ekonomi dan mampu berkontribusi dalam pembangunan perekonomian, diantaranya mengurangi pengangguran, meningkatkan kesejahteraan masyarakat dan mengurangi angka kemiskinan. Sebagaimana yang dapat dilihat dari perkembangan pengelolaan wakaf di berbagai negara yang mampu meningkatkan perekonomiannya, seperti Mesir yang mampu mengelola wakaf secara produktif baik wakaf tanah, gedung, lahan pertanian dan wakaf uang (Rozalinda: 2015). Selain itu, Sri Handayani (2008) dalam tesisnya menjelaskan bahwa bentuk aset wakaf di beberapa negara seperti Mesir, Yordania, Bangladesh, Saudi Arabia, Turki, dan Kuwait, selain berupa sarana dan prasarana ibadah kini juga berupa tanah pertanian, perkebunan, flat, hotel, pusat perbelanjaan, uang, dan saham yang semuanya dikelola secara produktif.

Wakaf uang di Indonesia juga memiliki potensi yang sama dengan negara-negara lain yang mampu mengelola secara produktif dan memberi kontribusi dalam perekonomian di Indonesia. Hal ini didukung dengan adanya potensi wakaf uang di Indonesia menurut Badan Wakaf Indonesia (BWI), yaitu sebesar 20 triliun rupiah. Angka ini didapat apabila 20 juta penduduk Indonesia atau sekitar 9\% dari total penduduk Indonesia mengalokasikan Rp1.000.000 per tahun untuk wakaf uang. Namun, faktanya penghimpunan wakaf uang belum efektif, terlihat dari jumlah wakaf yang terhimpun dari tahun 2011 sampai 2012 hanya berjumlah sekitar 3,6 milyar rupiah. 
Tabel 1. Data Jumlah Penerimaan Wakaf Uang Di Indonesia Tahun 2011-2012

\begin{tabular}{lllll}
\hline No & \multicolumn{1}{c}{ Nama LKS-PWU } & $\begin{array}{c}\text { Saldo Awal } \\
\text { Tahun 2011 } \\
(\mathbf{R p})\end{array}$ & $\begin{array}{c}\text { Peningkatan } \\
(\mathbf{R p )}\end{array}$ & $\begin{array}{c}\text { Saldo Akhir Tahun } \\
\mathbf{2 0 1 2}(\mathbf{R p})\end{array}$ \\
\hline 1. & $\begin{array}{l}\text { Bank Muamalat } \\
\text { Indonesia }\end{array}$ & 180.673 .114 & 182.200 .000 & 362.873 .114 \\
\hline 2. & Bank Syariah Mandiri & 1.944 .033 .140 & 281.352 .755 & 2.225 .385 .895 \\
\hline 3. & BNI Syariah & 487.003 .500 & 8.206 .434 & 495.209 .934 \\
\hline 4. & Bank DKI Syariah & 218.051 .410 & 53.714 .000 & 271.765 .410 \\
\hline 5. & Bank Mega Syariah & 225.573 .230 & 7.409 .300 & 233.982 .590 \\
\hline 6. & Bank Bukopin Syariah & 8.050 .000 & 18.451 .450 & 26.501 .450 \\
\hline 7. & Bank BTN Syariah & 3.000 .000 & 14.943 .100 & 17.943 .100 \\
\hline & Total & $\mathbf{3 . 0 6 7 . 3 8 4 . 4 5 4}$ & $\mathbf{5 6 6 . 2 2 7 . 0 3 9}$ & $\mathbf{3 . 6 3 3 . 6 6 1 . 4 9 3}$ \\
\hline
\end{tabular}

Sumber: BWI, 2011-2012 (Data diolah kembali)

Penghimpunan wakaf yang kurang optimal tersebut disebabkan karena masih sedikit wakaf yang dikelola secara profesional dan produktif. Menurut Kementrian Agama RI Tahun 2010, hampir 95\% aset wakaf belum dimanfaatkan secara optimal sehingga peran sosial-ekonomi wakaf belum maksimal. Good governance yang masih lemah menyebabkan kepercayaan masyarakat berkurang pada nadzir atau lembaga pengelola wakaf. ${ }^{1}$ Hasil penelitian yang dilakukan oleh Yuliafitri dan Arie mengenai Pengaruh Penerapan Prinsip-prinsip Good Governance dan promosi terhadap penerimaan wakaf tunai (Pada Lembaga Pengelola Wakaf di Indonesia) menunjukkan bahwa penerapan prinsip-prinsip good governance berpengaruh positif namun tidak signifikan terhadap penerimaan wakaf tunai, kemudian secara simultan penerapan prinsip-prinsip good governance dan promosi memiliki pengaruh positif yang signifikan terhadap penerimaan wakaf tunai.

Mengingat potensi wakaf uang yang besar tidak diiringi dengan penghimpunan yang efektif, maka Ikatan Cendekiawan Muslim Indonesia (ICMI) pada tahun 2014 menggagas pembentukan lembaga keuangan syariah berbasis wakaf. Menindaklanjuti gagasan tersebut, pemerintah pada tahun 2017 akan meresmikan Bank Wakaf Ventura sebagai lembaga penghimpun dan pengelola wakaf uang di Indonesia (cnnindonesia.com: 2017).

Pembentukan Bank Wakaf Ventura diharapkan mampu memberikan kemudahan bagi Usaha Mikro Kecil dan Menengah (UMKM) yang ingin melakukan pengajuan pembiayaan. Hal ini dikarenakan, UMKM menjadi salah satu tolak ukur dalam pertumbuhan ekonomi Indonesia. Namun, selama ini UMKM yang melakukan dan mendapatkan kredit untuk mengembangkan usaha masih kurang, dilihat dari pangsa kredit UMKM terhadap total kredit perbankan pada triwulan IV 2015 yaitu sebesar 19,9\% dari jumlah kredit yang telah dikeluarkan oleh perbankan di Indonesia (Bank Indonesia: 2015).

Teknologi yang digunakan oleh Bank Wakaf Ventura mempengaruhi efektivitas serta efisiensi penghimpunan dan pengelolaan wakaf uang. Hal ini sesuai dengan hasil penelitian yang dilakukan oleh Wardian selaku peneliti Pusat Penelitian Informatika-Lembaga Ilmu Pengetahuan Indonesia Komplek LIPI yang menyatakan bahwa perkembangan teknologi informasi dapat meningkatkan kinerja dan memungkinkan berbagai kegiatan dapat dilaksanakan dengan cepat, tepat, dan akurat, sehingga akhirnya akan meningkatkan produktivitas. Perkembangan tekno-

1Yuliafitri, Indri dan Arie Indra Rivaldi., Pengaruh Penerapan Prinsip-Prinsip Good Governance dan Promosi terhadap Penerimaan Wakaf Tunai (pada Lembaga Pengelola Wakaf di Indonesia). Jurnal InFestasi Volume 13 Nomor 1, Juni 2017, 2017 , h.89. 
logi informasi dibuktikan dengan munculnya berbagai jenis kegiatan yang berbasis pada teknologi, seperti e-goverment, e-commerce, e-education, e-medicine, e-laboratory, dan lainnya yang semuanya berbasis elektronik.

Selain itu hasil penelitian yang dilakukan oleh Maharsi, mengenai pengaruh perkembangan teknologi informasi terhadap bidang akuntansi manajemen memperlihatkan bahwa perkembangan teknologi informasi membawa perubahan yang signifikan dalam dunia bisnis. Teknologi informasi juga berpengaruh terhadap bidang akuntansi manajemen selaku bidang penghasil informasi dalam rangka perencanaan, pengendalian dan penambilan keputusan manajemen. ${ }^{2}$

Selain dari beberapa yang sudah disebutkan di atas, Dedrick dalam penelitiannya menyimpulkan tiga hal: (1) banyak penelitian yang sudah mengkonfirmasi bahwa teknologi informasi berdampak signifikan terhadap produktifitas perusahaan, industri, dan negara; (2) investasi pada teknologi informasi menjelang abad milenium mampu meningkatkan produktivitas; dan (3) teknologi informasi tidak dimaknai sebagai suatu alat yang sederhana untuk mengotomatisasi suatu pekerjaan, lebih penting dari itu adalah teknologi informasi mampu menciptakan perubahan pada organisasi untuk menghasilkan profit atau tingkat keuntungan yang lebih baik.

Pada era digitalisasi ini, bank ventura dapat memanfaatkan teknologi informasi sebagai solusi untuk kemudahan transaksi penghimpunan wakaf uang dari wakif kepada bank wakaf berbasis online menggunakan jaringan internet. Dimana saat ini, internet sangat popular dan masif digunakan oleh masyarakat Indonesia. Kondisi ini dibuktikan dengan data jumlah pengguna internet yang diklasifikasikan berdasarkan usia pengguna internet tahun 2016.

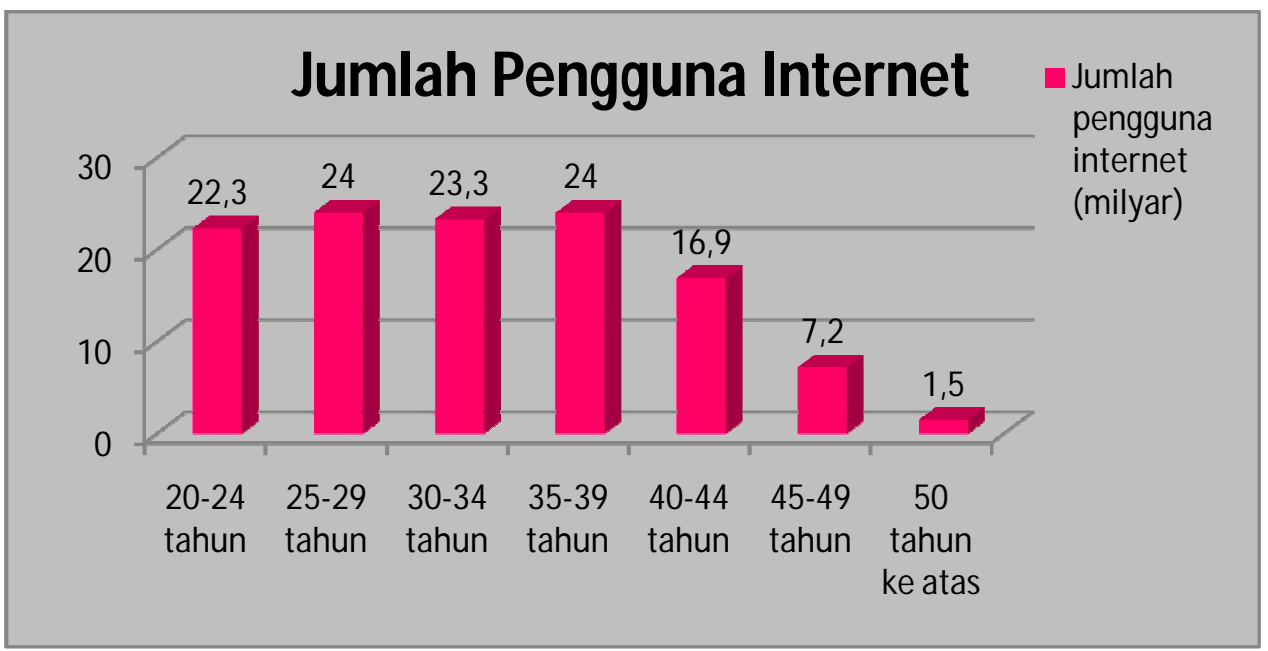

\section{Grafik 1. Statistik Pengguna Internet Indonesia Berdasarkan Usia Tahun 2016 Sumber: APJII, 2016 (Data diolah kembali)}

Berdasarkan data di atas, Asosiasi Penyedia Jasa Internet Indonesia (APJII) menjelaskan bahwa jumlah pengguna internet paling banyak berusia 25-29 tahun dan 35-39 tahun. Sementara itu, total pengguna internet dari usia 20 tahun hingga 50 tahun ke atas sebanyak 119,2 juta jiwa. Banyaknya pengguna internet di Indonesia, khususnya internet mobile, memungkinkan adanya integrasi antara sistem pembayaran online (e-payment) dengan pengefektifan penghimpunan dan pengelolaan harta wakaf berbasis pembayaran online (e-payment).

Penelitian ini fokus pada inovasi di bidang teknologi sistem informasi penghimpunan wakaf uang berbasis online dengan menggunakan aplikasi yang dapat memudahkan para peng-

\footnotetext{
2Maharsi, Sri, Pengaruh Perkembangan Teknologi Informasi Terhadap Bidang Akuntansi Manajemen. Jurnal Akuntansi dan Keuangan Volume 2 Nomor 2, November 2000, 2000, h. 127-137
} 
guna untuk menyalurkan dan memantau pendistribusian dana wakaf. Aplikasi ini diharapkan dapat mengembalikan kepercayaan publik terhadap pengelolaan wakaf uang.

\section{Tinjauan Pustaka}

\section{Wakaf}

Menurut bahasa, wakaf berasal dari bahasa arab waqafa yang berarti menahan atau berhenti di tempat. Menurut istilah, wakaf adalah penahanan harta yang dapat diambil manfaatnya tanpa musnah seketika dan untuk penggunaan yang mubah serta dimaksudkan untuk mendapatkan keridhaan Allah. Secara harfiah wakaf bermakna "Pembatasan" atau "larangan". Kata waqf digunakan dalam Islam untuk maksud "pemilikan dan pemeliharaan" harta benda tertentu untuk kemanfaatan sosial yang ditetapkan dengan maksud mencegah penggunaan harta wakaf tersebut di luar tujuan khusus yang telah ditetapkan tersebut. ${ }^{3}$

Dasar hukum wakaf secara khusus, nash yang menunjukan persyariatan wakaf dalam AlQur'an dan Hadist tidak ditemukan. Akan tetapi, secara umum banyak ditemukan ayat maupun hadist yang menganjurkan agar orang beriman menafkahkan sebagian rezekinya untuk kebaikan. Yang menjadi dasar wakaf adalah Q.S Ali Imran: 92.

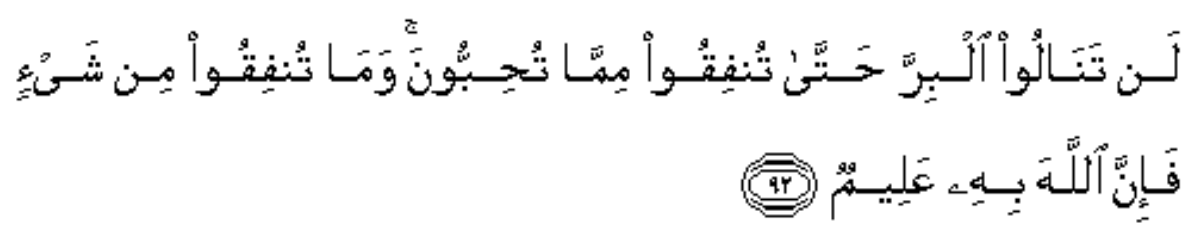

Artinya:

“Kamu sekali-kali tidak sampai kepada kebajikan (yang sempurna), sebelum kamu menafkahkan sebahagian harta yang kamu cintai. Dan apa saja yang kamu nafkahkan, maka sesungguhnya Allah mengetahuinya." (Q.S Ali Imran: 92)

\section{Wakaf Produktif}

Wakaf dalam perspektif ekonomi dapat diartikan sebagai pengalihan dana (atau asset lainnya) dari keperluan konsumsi dan menginvestasikannya ke dalam asset produktif yang menghasilkan pendapatan untuk konsumsi di masa yang akan datang baik oleh individual ataupun kelompok. Wakaf dapat dibagi menjadi dua kategori, pertama direct waqf dimana asset yang ditahan atau diwakafkan dapat menghasilkan manfaatatau jasa yang kemudian dapat digunakan oleh orang banyak (beneficiaries) seperti rumah ibadah, sekolah dan lain-lain. Kedua, wakaf investasi (asset yang diwakafkan digunakan untuk investasi). Wakaf asset ini dikembangkan untuk menghasilkan pendapatan, dimana pendapatan tersebut kemudian digunakan untuk membangun fasilitas-fasilitas umum seperti masjid, pusat kegiatan umat muslim dan lain-lain.4

Objek wakaf di beberapa negara yang berpenduduk muslim tidak lagi didominasi dan hanya terbatas pada benda tidak bergerak, seperti tanah dan bangunan.akan tetapi telah berkembang pada asset tidak tetap, seperti uang dan surat berharga. Saat ini wakaf dalam bentuk uang telah diterima luas diberbagai negara Islam seperti Turki, Mesir, India, Pakistan, Singapura, Malaysia termasuk Indonesia. ${ }^{5}$

\footnotetext{
${ }^{3}$ Wadjdy, Farid dan Mursyid, Wakaf dan Kesejahteraan Umat (Filantropi Islam yang Hampir Terlupakan). Yogyakarta: Pustaka Pelajar, 2007, h.45.

${ }^{4}$ Ibid.

${ }^{5}$ Rozalinda, Manajemen Wakaf Produktif. Jakarta: PT Rajagrafindo Persada, 2015, h. 45.
} 


\section{Wakaf Uang}

Wakaf uang atau sering disebut dengan wakaf tunai adalah wakaf yang dilakukan seseorang, kelompok orang dan lembaga atau badan hukum dalam bentuk uang tunai. yang termasuk kedalam pengertian uang dalah surat-surat berharga, seperti saham, cek dan lainnya. Komisi Fatwa Majelis Ulama Indonesia pun telah menetapkan fatwa tentang wakaf uang sebagai berikut.

1. Wakaf uang (cash waqf/ waqf al nuqud) adalah wakaf yang dilakukan seseorang, kelompok orang, lembaga atau badan hukum dalam bentuk uang tunai.

2. Termasuk ke dalam pengertian uang adalah surat-surat berharga.

3. Wakaf uang hukumnya jawaz (boleh).

4. Wakaf uang hanya boleh disalurkan dan digunakan untuk hal-hal yang diperbolehkan secara syar'i.

5. Nilai pokok wakaf uang harus dijamin kelestariannya, tidak boleh dijual, dihibahkan, dan atau diwariskan.

Lahirnya fatwa diatas menjadikan dasar disahkannya undang-undang wakaf tahun 2004. Undang-Undang Nomor 41 Tahun 2004 pasal 28 menjelaskan tentang wakaf benda bergerak yang menyatakan bahwa wakif dapat mewakafkan benda bergerak berupa uang melalui lembaga kauangan syariah yang ditunjuk oleh menteri.

Wakaf uang atau wakaf tunai mempunya empat manfaat: 6

1. Jumlahnya bisa bervariasi sehingga seseorang yang memiliki dan terbatas sekalipun sudah bisa memberikan dana wakafnya, tanpa harus menunggu menjadi tuan tanah atau konglomerat.

2. Asset wakaf yang berupa tanah kosong bisa mulai dimanfaatkan dengan pembangunan gedung atau diolah untuk lahan pertanian.

3. Wakaf tunai juga bisa membantu sebagian lembaga pendidikan Islam.

4. Ummat Islam dapat lebih mandiri dalam mengembangkan dunia pendidikan tanpa harus selalu tergantung pada anggaran pendidikan negara yang memang semakin lama semakin terbatas.

\section{Implementasi Wakaf Uang di Indonesia}

Wakaf uang muncul karena ada berbagai masalah dalam pengeolaan harta wakaf tidak bergerak. Harta wakaf seperti tanah tidak dikelola dengan baik, salah satu penyebabnya adalah karena tidak ada dana yang cukup untuk mengelolanya. Kemudian wakaf uang hadir sebagai alternatif sumber dana pengelolaan harta wakaf.

BWI dalam menghimpun wakaf uang bekerja sama dengan Lembaga Keuangan Syariah Penerima Wakaf Uang (LKS PWU). Masyarakat yang ingin berwakaf harus datang ke LKS PWU yang telah ditunjuk oleh BWI seperti Bank Muamalat Indonesia dan Bank BPD Syariah DIY. Kemudian wakif mengisi Akta Ikrar Wakaf (AIW) yang disediakan oleh LKS PWU. Setelah itu wakif menyetorkan uang yang ingin diwakafkan dan mengucap sighoh (ijab Kabul). LKS PWU kemudian mencetak sertifikat wakaf uang untuk wakif tersebut.

\footnotetext{
${ }^{6} \mathrm{Hak}$, Nurul, Ekonomi Islam Hukum Bisnis Syarah: Mengupas Ekonomi Islam, Bank Islam, Bunga Uang dan Bagi Hasil, Wakaf Uang dan Sengketa Ekonomi Syariah. Yogyakarta: Teras, 2011, h.78.
} 


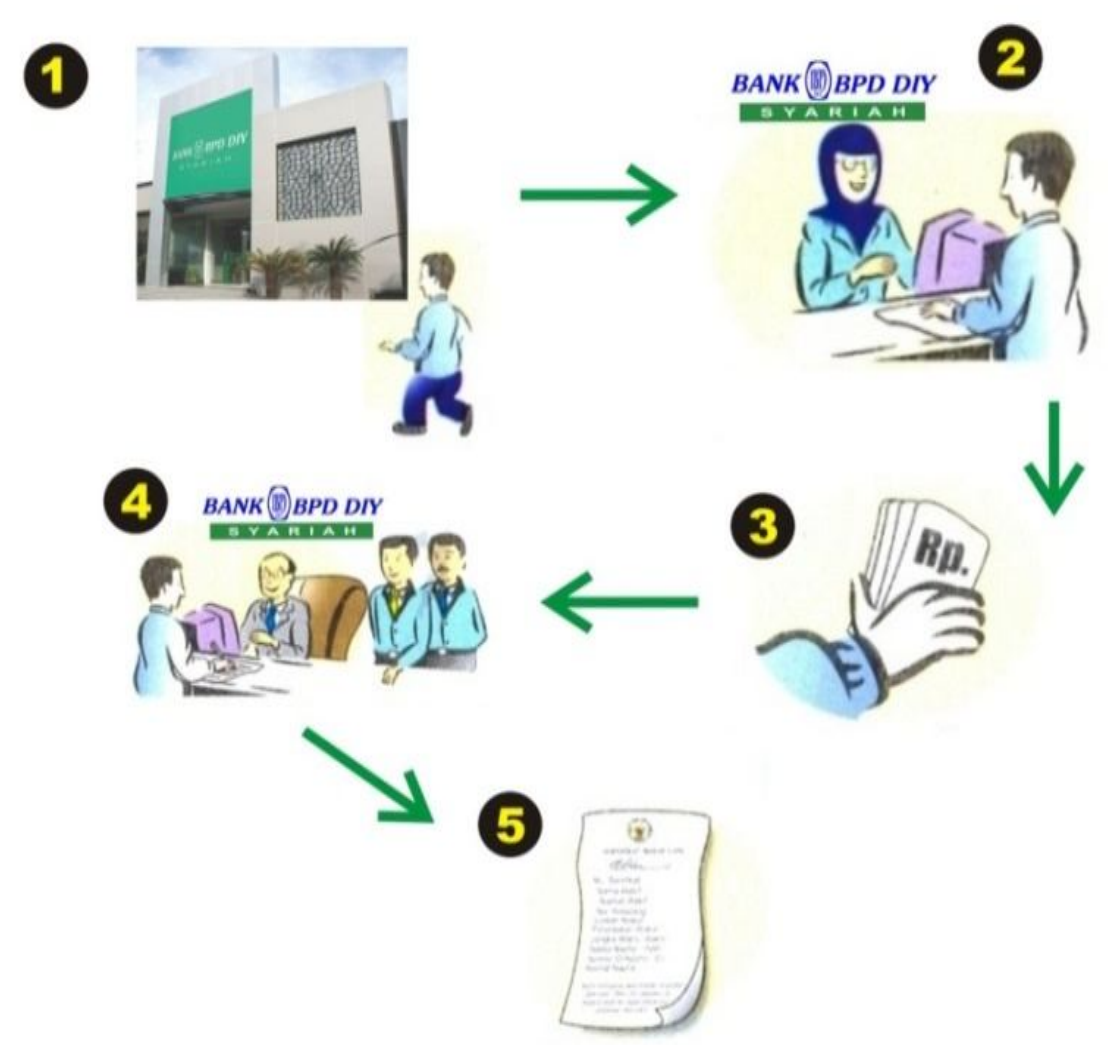

\section{Skema 1. Alur Pembayaran Wakaf Uang Melalui LKS PWU}

Untuk mengkaji lebih lanjut mengenai implementasi wakaf uang di Indonesia, penulis melakukan wawancara dengan Bapak M. Yazid Affandi, M. Ag. selaku Ketua dari LAZISNU Yogyakarta. Menurut Beliau, sampai sekarang penghimpunan wakaf uang masih terkendala stigma masyarakat yang cenderung konservatif. Sosialisasi dan edukasi yang dilakukan belum menyeluruh sehingga masyarakat belum memahami ugensi wakaf uang.

Selain hal tersebut, Bapak Yazid Affandi juga mengatakan bahwa terdapat beberapa kelemahan dalam sistem pengelolaan wakaf yang ada saat ini, antara lain seperti berikut.

1. Regulasi

Pemerintah selaku pembuat kebijakan seringkali terlambat dalam merespon fenomena yang terjadi dalam masyarakat. Kebijakan yang dikeluarkan oleh pemerintah seringkali dibuat ketika fenomena telah menjadi kebiasaan dalam masyarakat. seperti dalam konteks wakaf, dimana masyarakat telah mempraktikan wakaf sejak Islam masuk ke Indonesia. Namun, pemerintah baru membuat Undang-Undang wakaf pada tahun 2004 dengan diterbitkannya UU No. 41 tahun 2004 tentang wakaf. Sebelumnya terdapat beberapa peraruran yang mengatur tentang wakaf. Salah satunya adalah UU No. 5 tahun 1960 tentang Peraturan Dasar Pokok-Pokok Agraria. Namun dalam undang-undang tersebut wakaf hanya dibahas pada tiga pasal, yaitu pada pasal lima, 14 (1) dan 49.

2. Fleksibilitas Pembayaran Wakaf

Pembayaran wakaf uang yang dilakukan di Indonesia saat ini masih berbasis official assessment system dimana wakif harus mendatangi LKS PWU. Sistem pembayaran ini memiliki kelemahan ketika wakif tidak dapat mendatangi langsung LKS PWU maka wakif tidak dapat berwakaf. Hal ini menjadi salah satu faktor penyebab potensi wakaf uang belum dapat terhimpun secara efektif. 


\section{Profesionalitas nadzir}

Nadzir sebagai pengelola wakaf seharusnya memiliki kreativitas dan inovasi dalam pengelolaan harta wakaf. Sehingga harta wakaf dapat berkembang dan mampu memberikan manfaat pada masyarakat serta mampu meningkatkan perekonomian Indonesia. Faktanya di Indonesia pengelolaan harta wakaf masih terbatas karena kurangnya kreativitas nadzir dalam mengelola wakaf. Oleh karenanya harta wakaf kurang berkembang dan kurang mampu memberikan manfaat bagi masyarakat.

4. Pengetahuan dan stigma masyarakat terhadap wakaf uang

Masyarakat Indonesia masih beranggapan bahwa benda yang boleh diwakafkan hanya benda yang tidak bergerak saja seperti tanah dan bangunan. Stigma tersebut membatasi orang yang ingin berwakaf karena hanya orang kaya yang bisa berwakaf. Padahal seharusnya siapapun bisa berwakaf tanpa harus menunggu kaya.

\section{Bank Wakaf Ventura}

Menurut Prof. Dr. Mohammad Tahir Sabit Haji Mohammad dari Universiti Teknologi Malaysia, bank wakaf didefinisikan sebagai lembaga yang terlepas dari segala orientasi keuntungan ekonomi dan didedikasikan penuh untuk kesejahteraan sosial yaitu dengan memberi pembiayaan kepada usaha kecil serta berfokus pada pembangunan ekonomi masyarakat marjinal.7

Pada penelitian sebelumnya yang membicarakan tentang "Model Bank Wakaf di Indonesia dalam Potensinya untuk Mengembangkan Wakaf Uang dan Mengatasi Kemiskinan" merumuskan fungsi bank wakaf sebagai penghimpun dan pengelola dana wakaf dari masyarakat yang selanjutnya keuntungannya digunakan sebagai dana untuk membangun ekonomi di Indonesia.

Melihat potensi wakaf di indonesia Ikatan Cendekiawan Muslim Indonesia (ICMI) pada tahun 2014 menggagas pembentukan lembaga keuangan syariah berbasis wakaf. Menindaklanjuti gagasan tersebut, pemerintah pada tahun 2017 akan meresmikan Bank Wakaf Ventura sebagai lembaga penghimpun dan pengelola wakaf uang di Indonesia.

Sebanyak 20 organisasi masyarakat di Indonesia dengan tiga organisasi masyarakat pengendali, yaitu Badan Amil Zakat Nasional (BAZNAS), Badan Wakaf Indonesia (BWI), dan Badan Pengelola Keuangan Haji (BPKH) turut serta dalam penyertaan modal ventura pada pembentukan Bank Wakaf Ventura ini. Dengan dipilihnya modal ventura untuk bank wakaf ini maka akan ada kombinasi dari sumber pendanaan bagi bank wakaf tersebut.

\section{E-payment}

Electronic payment atau sering disebut e-payment merupakan pembayaran yang dilakukan secara elektronik. Di dalam pembayaran elektronik uang disimpan, diproses, dan diterima dalam bentuk informasi digital dan proses pemindahannya diinisialisasi melalui alat pembayaran elektronik. Komponen-komponen utama dalam pembayaran elektronik antara lain: ${ }^{8}$

1. aplikasi pemindahan uang;

2. infrastruktur jaringan; dan

3. peraturan dan prosedur yang memerintah keuangan dari sistem tersebut.

\footnotetext{
${ }^{7}$ Mohammad, T.S., Towards an Islamic Social (Waqf) Bank. International Journal of Trade, Economics and Finance. Vol. 2 No. 5. Hak, Nurul, Ekonomi Islam Hukum Bisnis Syarah: Mengupas Ekonomi Islam, Bank Islam, Bunga Uang dan Bagi Hasil, Wakaf Uang dan Sengketa Ekonomi Syariah. Yogyakarta: Teras, 2011, h. 381-386.

${ }^{8}$ Trihasta, Deni dan Julia Fajaryanti, E-Payment Sistem. Proceeding, Seminar Ilmiah Nasional Komputer dan Sistem Intelijen (KOMMIT 2008). ISSN: 1411-6286, 2008, h.168.
} 
Pembayaran elektronik dapat meningkatkan efisiensi pembayaran secara drastis dengan mengurangi biaya transaksi dan memperbolehkan perdagangan barang dan jasa dengan nilai yang sangat rendah.pembayaran secara elekronik bertujuan untuk memudahkan kehidupan bagi orang-orang yang sibuk. E-payment juga dapat meningkatkan kenyamanan dari pembayaran dengan memperbolehkan transaksi-transaksi tersebut dilakukan secara cepat dan lebih efisien/ praktis dari berbagai macam alat yang terhubung kapada jaringan global. ${ }^{9}$

\section{METODE}

\section{Jenis Penelitian}

Dalam penelitian ini, penulis menggunakan jenis penelitan studi lapangan dan wawancara, di mana penulis bertujuan untuk memperoleh informasi secara detail dan mendalam dari narasumber yang diwawancarai. Penulis juga menggunakan jenis penelitian library research, di mana permasalahan digambarkan dengan didasari pada data-data yang terdapat dalam literatur atau dokumen. Kemudian dianalisis lebih lanjut untuk diambil suatu kesimpulan.

\section{Jenis Data}

Menggunakan data primer dan sekunder. Data primer merupakan sumber data penelitian yang diperoleh secara langsung dari sumber asli dengan kata lain data diperoleh tidak melalui perantara.Sementara itu, data sekunder merupakansumber data penelitian yang diperoleh peneliti secara tidaklangsung melalui media perantara. ${ }^{10}$ Dimana data primer diperoleh dari studi lapangan yang berupa kuisioner dan wawancara, sedangkan data sekunder bersumber dari studi kepustakaan.

\section{Teknik Pengumpulan Data}

Dalam pengumpulan data,penulis menggunakan teknik probability sampling.Probability sampling adalah metode pemilihan sampel dengan menggunakan konsep bahwa setiap elemen populasi mempunyai probabilitas yang sama untuk terpilih sebagai sampel. ${ }^{11}$

\section{Teknik Analisis}

Dalam menganalisis data, penulis menggunakan analisis deskriptif, dimana data atau informasi digambarkan berdasarkan fakta-fakta yang diperoleh. Selain itu, penulis juga menggunakan conjoint analysissebagai teknik untuk menentukan tingkat kepentingan relatif berdasarkan persepsi responden yang digunakan untuk mementukan konten aplikasi yang paling disukai oleh responden. Hair, dkk menjelaskan conjoint analysismerupakan salah atu teknik analisis multivariat yang dikembangkan untuk memahami bagaimana responden memilih beberapa alternatif pilihan yang disukai dari produk, jasa dan ide secara spesifik.12

\section{Kerangka Berfikir}

Penulis melakukan simplifikasi penelitian yang tercermin pada kerangka penelitian sebagai berikut ini.

\footnotetext{
9Ibid.

10Indriantoro, Nur dan Bambang Supomo, Metodologi Penelitian Untuk Akuntansi dan Manajemen. Yogyakarta: BPFE Yogyakarta, 2016, h. 25

11Ibid., h. 28.

${ }^{12}$ Hair, Joseph F, dkk, Multivariate Data Analysis A Global Perspective. United Kingdom: Pearson, 2009, h. 68.
} 


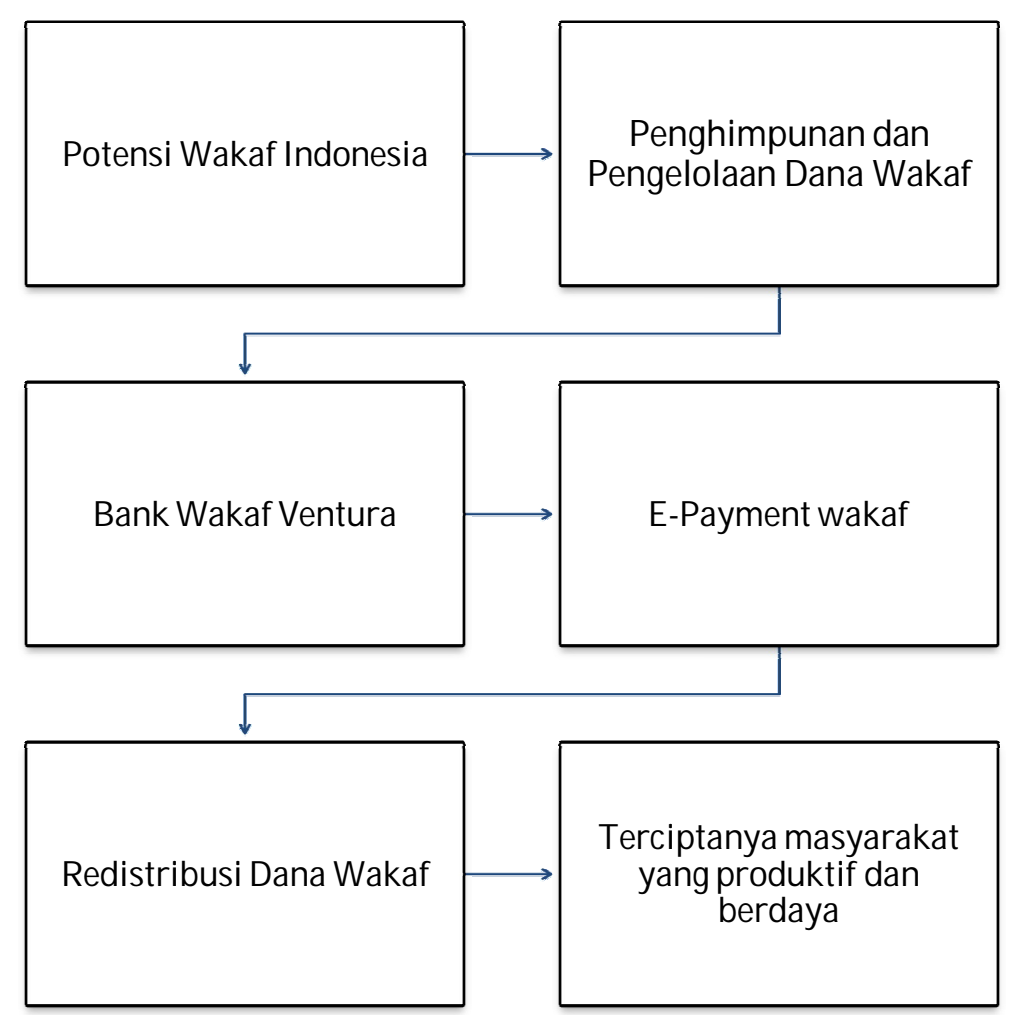

\section{HASIL DAN PEMBAHASAN}

\section{Model Penerapan Bank Wakaf Ventura}

Banyaknya lembaga wakaf di Indonesia tidak menjamin penghimpunan dana wakaf yang efektif, terbukti dengan masih sedikitnya dana wakaf yang terhimpun dibandingkan dengan potensi wakaf yang ada. Hal tersebut dikarenakan lembaga wakaf-lembaga wakaf tersebut kurang memiliki kemampuan atau kekuasaan untuk berinovasi dalam usaha penghimpunan dana wakaf itu sendiri. Dana wakaf yang terhimpun pun tidak kunjung mengalami peningkatan yang signifikan. Hal itu berdampak pada pendayagunaan dana wakaf yang kurang dapat dimanfaatkan dengan baik pula.

Solusi untuk mensejahterakan masyarakat dalam Islam salah satunya melalui wakaf, dimana manfaat dari harta wakaf ini ditujukan untuk kemaslahatan umat. Ketika harta wakaf dapat dikelola dengan baik, maka manfaat yang akan didapat oleh masyarakat tentu akan lebih besar. Kesuksesan dalam pengelolaan harta wakaf tak lepas dari adanya himpunan dana yang mencukupi. Sehingga penghimpunan dana pun menjadi salah satu faktor yang penting.

Dalam rangka membantu penghimpunan harta wakaf, khususnya wakaf uang, pemerintah pun akan membentuk Bank Wakaf dengan skema ventura. Adanya bank wakaf ventura ini diharapkan akan menjadikan pembayaran wakaf uang menjadi lebih terfokus. Disisi lain dengan adanya kerjasama dengan lembaga wakaf juga akan mengintegrasikan pengelolaan wakaf. Adapun konsep penerapan bank wakaf yang ditawarkan dapat dilihat pada Skema 1.

Skema penerapan bank wakaf venturan di atas menjelaskan bahwa berdirinya bank ventura di bawah OJK dan Kemenag yang membatu melegalkan bank wakaf ventura. Dimana pelaksanaan bank wakaf ventura diawasi langsung oleh Badan Wakaf Indonesia (BWI). Kemudian Bank wakaf ventura akan menyalurkan dana yang dihimpun dari penghimpunan wakaf uang secara elektronik atau e-payment kepada lembaga-lembaga wakaf. Selain mendapatkan dana wakaf dari bank wakaf ventura, lembaga wakaf kemudian meredistribusikan dana wakaf kepada 
mauquf alaih. Dimana penyaluran yang dilakukan oleh lembaga wakaf kepada mauquf alaih dilakukan secara profesional dan dikelola secara produktif, serta dana yang disalurkan kepada mauquf alaih menggunakan akad mudarabah yang mana lembaga wakaf memberikan modal usaha kepada mauquf alaih kemudian mauquf alaih bekerja atau memanfaatkan modal tersebut guna mendapatkan imbal hasil dari usaha yang dilakukan mauquf alaih.

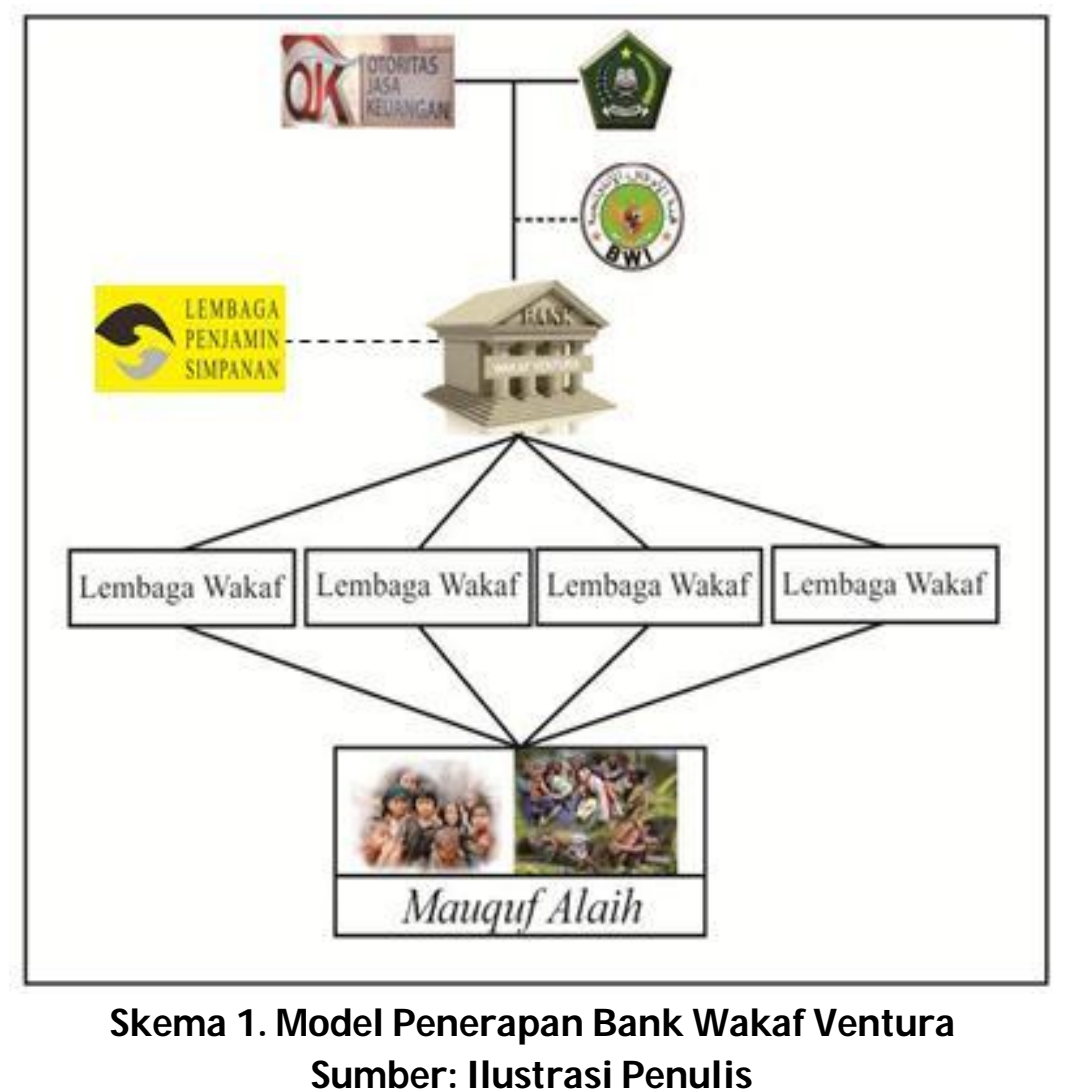

\section{E-payment Wakaf Uang Sebagai Sarana Peningkatan Penghimpunan Wakaf Uang}

Laudon at al. (2014) menjelaskan bahwa prototype merupakan versi sistem informasi atau bagian dari sistem yang sudah dapat berfungsi, tetapi dimaksudkan hanya sebagai model awal saja. Untuk itu penulis mencoba memvisualisasikan model e-payment yang dapat digunakan sebagai layanan penghimpunan dan redistribusi wakaf uang. Prototipe ini dapat digunakan sebagai gambaran awal mengenai aplikasi e-epayment.

Aplikasi e-payment wakaf merupakan suatu alat pembayaran wakaf uang modern menggunakan sistem pembayaran berbasis self assessment system yang terintegrasi secara online. Dengan memanfaatkan aplikasi e-payment wakaf, wakif dapat melakukan pembayaran wakaf atau mengisi setoran wakaf kapan saja dan dimana saja. Penerapan aplikasi ini diharapkan mampu meningkatkan jumlah wakif di Indonesia. Meningkatnya jumlah wakif di Indonesia akan selaras dengan peningkatan penerimaan harta wakaf. Sehingga potensi wakaf uang yang ada dapat terhimpun secara efektif.

Penggunaan aplikasi E-payment wakaf uang diawali dengan membuka rekening Bank Wakaf melalui pengisian formulir online yang telah disediakan pada website Bank Wakaf. Setelah mengisi formulir, wakif akan mendapatkan e-mail dari Bank Wakaf yang berisi nomor rekening dan password. Artinya, wakif telah terdaftar sebagai nasabah Bank Wakaf. Nomor 
rekening dan password tersebut dapat digunakan wakif untuk aktivasi dan log in aplikasi E-payment yang telah di-download pada Google Play Store atau Apple Store.
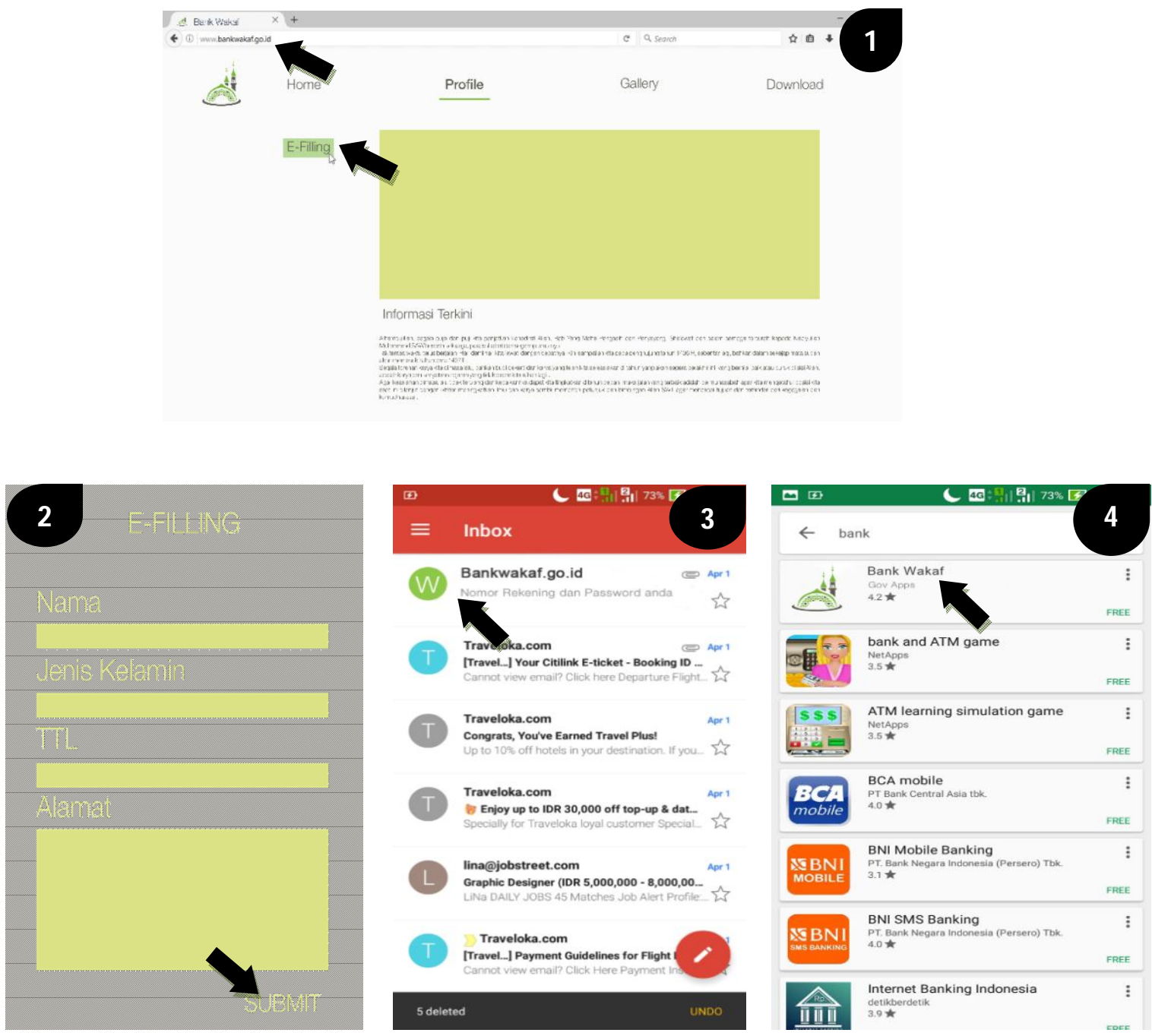

\section{7}

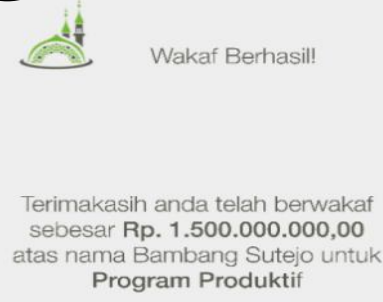

a telah berwaka Program Produktif

\section{6}

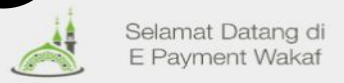

Isi Saldo

Rp. 1.500 .000 .000

Peruntukan wakaf

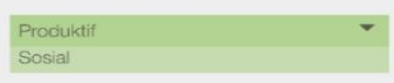

WAKAF SEKARANG
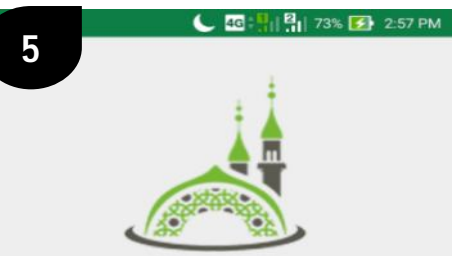

Nomor Rekening

Password

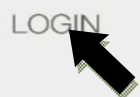


Wakif kemudian dapat menyetorkan saldo wakaf dari rekening bank komersial yang dimiliki melalui aplikasi e-payment wakaf. Setelah saldo terisi, wakif kemudian memilih peruntukan wakaf yang diinginkan, seperti wakaf untuk pemberdayaan UMKM, wakaf untuk pengembangan pendidikan, wakaf untuk pemberdayaan pertanian, dll. Dipilihnya peruntukan wakaf oleh wakif menjadi pengganti sighoh sebagai salah satu rukun wakaf. Seperti halnya dalam jual beli, sighoh juga menjadi salah satu rukun jual-beli. Tetapi dalam prakteknya, sighoh dapat dilakukan dengan diberikannya uang kepada pembeli sebagai bentuk serah terima pembelian barang. Setelah semua tahap dilakukan. Wakif kemudian mencetak Sertifikat Wakaf Uang (SWU) sebagai bukti pembayaran wakaf. Alur penggunaan aplikasi e-payment di atas, tergambar dalam Skema 2.

\section{E-payment Wakaf Uang Sebagai Sarana Redistribusi Harta Wakaf}

Redistribusi dapat diartikan sebagai penyebaran kekayaan dari suatu masyarakat ke masyarakat tertentu secara tunai maupun dengan cara yang lain. Dalam teori redistribusi ini, terdapat dua pihak yang terlibat, yaitu pihak yang kelebihan dana dan pihak yang kekurangan dana. Pihak yang kelebihan dana akan memberikan dana kepada pihak yang kekurangan dana. Dalam penyebaran atau penyaluran dana tersebut terdapat perantara (intermediary) atau dapat disebut agen redistribusi. Agen redistribusi mencakup pemerintah, lembaga swasta, dan perorangan.

Model redistribusi yang dibuat merupakan pengembangan dari model pengelolaan dan penyaluran hasil wakaf uang pada model bank wakaf di Indonesia. Penerapan model redistribusi harta wakaf melibatkan beberapa pihak, diantaranya wakif sebagai pihak yang kelebihan dana, mauquf alaih sebagai pihak yang kekurangan dana, serta bank wakaf sebagai agen redistribusi. Bank wakaf memiliki peran sebagai nadzir yang mengelola harta wakaf sehingga harta wakaf dapat berkembang.Penyaluran manfaat harta wakaf dilakukan melalui dua cara, pertama bank wakaf menyalurkan manfaat harta wakaf langsung kepada mauquf alaih. Kedua, manfaat harta wakaf disalurkan melalui lembaga wakaf yang ada di Indonesia dan selanjutnya akan diberikan kepada mauquf alaih dengan adanya pendampingan-pendampingan yang diperlukan.

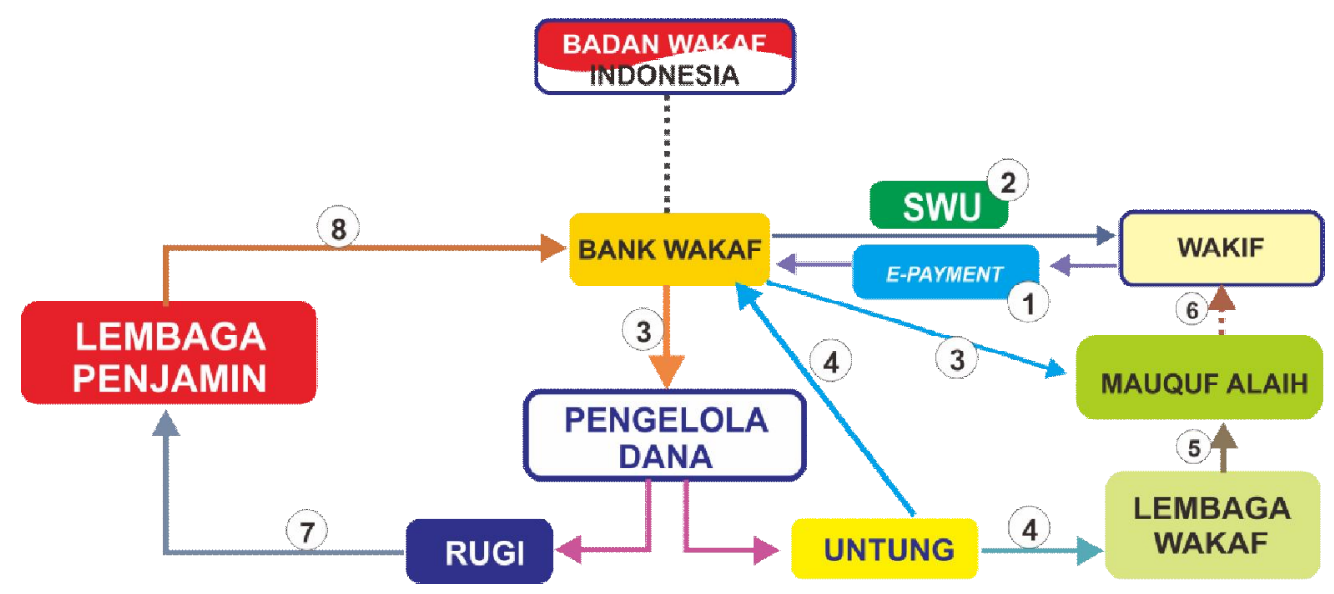

\section{Skema 3. Model Redistribusi Harta Wakaf Sumber: Ilustrasi Penulis}

Penyaluran harta wakaf tidak akan berjalan efektif apabila tidak ada harta wakaf yang terhimpun. Selama ini, penghimpunan wakaf uang terkendala dengan kurangnya fleksibilitas dalam membayar wakaf, karena wakif harus datang ke LKS PWU yang telah ditunjuk oleh BWI. 
Oleh karena itu, dibutuhkan suatu inovasi baru yang akan memudahkan wakif dalam membayar wakaf. Di sinilah peran e-payment wakaf dibutuhkan. Aplikasi E-payment wakaf akan memungkinkan wakif untuk berwakaf kapan dan dimana saja. Kemudahan yang ada ini, diharapkan akan selaras dengan peningkatan penerimaan wakaf uang di Indonesia.

Terlebih lagi ketika potensi wakaf uang di Indonesia mampu terhimpun secara efektif serta dikelola secara produktif dan profesional oleh nadzir maka harta wakaf dapat memberikan kontribusi terhadap peningkatan perekonomian masyarakat Indonesia.

\section{PENUTUP}

\section{Simpulan}

Berdasarkan analisis teori dan pembahasan, dapat ditarik kesimpulan sebagai berikut.

Pertama,Indonesia mempunyai potensi wakaf uang yang besar, namun potensi tersebut belum mampu terhimpun secara efektif. Potensi wakaf uang di Indonesia menurut Badan Wakaf Indonesia (BWI) yaitu sebesar 20 triliun rupiah. Angka ini didapat apabila 20 juta penduduk Indonesia atau sekitar 9\% dari total penduduk Indonesia mengalokasikan Rp1.000.000 per tahun untuk wakaf uang. Namun faktanya penghimpunan wakaf uang belum efektif, terlihat dari jumlah wakaf yang terhimpun dari tahun 2011 sampai 2012 hanya berjumlah sekitar 3,6 milyar rupiah.

Kedua, mengingat potensi wakaf uang yang besar tidak diiringi dengan penghimpunan yang efektif, oleh karena itu pemerintah pada tahun 2017 akan meresmikan Bank Wakaf Ventura sebagai lembaga penghimpun dan pengelola wakaf uang di Indonesia. Bank wakaf ventura berfungsi sebagai penghimpun dan juga pengelola wakaf uang yang bekerja sama dengan lembaga-lembaga wakaf yang ada. Pembentukan bank wakaf ventura ini bertujuan untuk mengefektifkan penghimpunan dan pengelolaan wakaf uang yang ada di Indonesia.

Ketiga, Alur transaksi yang dilakukan oleh wakif untuk berwakaf pada Bank Wakaf Venturaadalah Masyarakat yang ingin berwakaf harus datang ke Bank wakaf. Kemudian wakif mengisi Akta Ikrar Wakaf (AIW) yang disediakan. Setelah itu wakif menyetorkan uang yang ingin diwakafkan dan mengucap sighoh (ijab Kabul). Bank Wakaf Ventura kemudian mencetak sertifikat wakaf uang untuk wakif tersebut.E-payment wakaf memudahakan wakif untuk melakukan transaksi dan membantu bank wakaf ventura dalam menghimpun dan mengelola wakaf uang yang terkumpul.

Keempat, penerapan model redistribusi harta wakaf melibatkan beberapa pihak, diantaranya wakif sebagai pihak yang kelebihan dana, mauquf alaih sebagai pihak yang kekurangan dana, serta bank wakaf sebagai agen redistribusi. Bank wakaf memiliki peran sebagai nadzir yang mengelola harta wakaf sehingga harta wakaf dapat berkembang. Potensi wakaf uang mampu terhimpun secara efektif dan dikelola secara produktif dan profesional oleh nadzir maka harta wakaf dapat memberikan kontribusi terhadap peningkatan perekonomian masyarakat Indonesia.

\section{Saran}

Mengingat potensi wakaf di Indonesia yang sangat besar dan kendala-kendala yang ada dalam penghimpunan dan pengelolaan wakaf uang, maka disarankan hal-hal seperti berikut.

1. Adanya transformasi pembayaran wakaf uang dari official assesment system ke self assesment system sehingga Bank Wakaf perlu menerapkan konsep dan aplikasi e-payment agar mempermudah dalam penghimpunan wakaf uang. 
2. Adanya edukasi kepada masyarakat mengenai aplikasi e-payment. Sebelum penerapan dan penggunaan aplikasi e-payment, perlu adanya sosialisasi dan edukasi kepada masyarakat mengenai aplikasi e-payment tersebut.

3. Perlu adanya support atau dukungan dari pemerintah dan lembaga terkait mengenai penerapan konsep dan aplikasi e-payment.

\section{Keterbatasan Penelitian}

1. Penelitian ini masih bersifat konseptual (belum bersifat empiris) karena belum dilakukan pengujian apakah aplikasi e-payment wakafberpengaruh signifikan terhadap pembangunan ekonomi nasional.

2. Keterbatasan database sehingga data yang digunakan merupakan data tahun terakhir yang dapat diakses.

\section{DAFTAR PUSTAKA}

Arif, Syarifudin. 2010. Wakaf Tunai Sebagai Alternatif Mekanisme Redistribusi Keuangan Islam. Jurnal Ekonomi Islam. Volume IV No.1. Halaman 110

Donna, Dudy Roesmana. 2017. Tantangan Optimalisai Wakaf Tunai dan Urgensi Pembentukan Bank Wakaf di Indonesia. $2^{\text {nd }}$ Mashudi Monthly Disscusion Fossei Yogyakarta.

Hair, Joseph F, dkk. 2009. Multivariate Data Analysis A Global Perspective. United Kingdom: Pearson.

Hak, Nurul. 2011. Ekonomi Islam Hukum Bisnis Syarah: Mengupas Ekonomi Islam, Bank Islam, Bunga Uang dan Bagi Hasil, Wakaf Uang dan Sengketa Ekonomi Syariah. Yogyakarta: Teras.

Handayani, Sri. 2008. Pelaksanaan Wakaf Uang Dalam Perspektif Hukum Setelah Berlakunya Undang-Undang Nomor 41 Tahun 2004 Tentang Wakaf di Kota Semarang. Semarang: Universirtas Diponegoro.

Havita, Gusva, Kartika Arum S, Silvia Ranny W. 2013. Model Bank Wakaf di Indonesia dalam Potensinya untuk Mengembangkan Wakaf Uang dan Megatasi Kemiskinan. Proceedings Pekan Ilmiah Mahasiswa Nasional.

Hedrick, Jason, Vijay Gurbaxani, dan Kenneth L. Kraemer. 2003. Information Technology and Economic Performance: A Critical Review of The Empirical Evidence. ACM Computing Surveys, Volume 35 Nomor 1, Maret 2003. Halaman 1-28

Indriantoro, Nur dan Bambang Supomo, Metodologi Penelitian Untuk Akuntansi dan Manajemen. Yogyakarta: BPFE Yogyakarta, 2016.

Laudon, Kenneth C dan Jane P. Laudon. 2014. Sistem Informasi Manajemen Mengelola Perusahaan Digital.Jakarta: Salemba Empat.

Maharsi, Sri. 2000. Pengaruh Perkembangan Teknologi Informasi Terhadap Bidang Akuntansi Manajemen. Jurnal Akuntansi dan Keuangan Volume 2 Nomor 2, November 2000: 127 137. 
Mohammad, T.S., Towards an Islamic Social (Waqf) Bank. International Journal of Trade, Economics and Finance. Vol. 2 No. 5. Hak, Nurul, Ekonomi Islam Hukum Bisnis Syarah: Mengupas Ekonomi Islam, Bank Islam, Bunga Uang dan Bagi Hasil, Wakaf Uang dan Sengketa Ekonomi Syariah. Yogyakarta: Teras, 2011, Halaman 381-386.

Mohammad, T.S. 2011. Permissibility of Establishingwaqf Bank in Islamic Law. Proceeding of International Conference on Society and Economics Development. Kuala Lumpur, 17-19 June 2011. Kuala Lumpur: University Technology Malaysia. Halaman: 250-254.

Rozalinda, Manajemen Wakaf Produktif. Jakarta: PT Rajagrafindo Persada, 2015.

Trihasta, Deni dan Julia Fajaryanti, E-Payment Sistem. Proceeding, Seminar Ilmiah Nasional Komputer dan Sistem Intelijen (KOMMIT 2008). ISSN: 1411-6286, 2008.

Wadjdy, Farid dan Mursyid, Wakaf dan Kesejahteraan Umat (Filantropi Islam yang Hampir Terlupakan). Yogyakarta: Pustaka Pelajar, 2007.

Wardiana, Wawan. 2002. Perkembangan Teknologi Informasi di Indonesia. Disampaikan pada Seminar dan Pameran Teknologi Informasi 2002, Fakultas Teknik Universitas Komputer Indonesia (UNIKOM) Jurusan Teknik Informatika Informatika, tanggal 9 Juli 2002.

Yuliafitri, Indri dan Arie Indra Rivaldi. 2017. Pengaruh Penerapan Prinsip-Prinsip Good Governance dan Promosi terhadap Penerimaan Wakaf Tunai (pada Lembaga Pengelola Wakaf di Indonesia). Jurnal In Festasi Volume 13 Nomor 1, Juni 2017. 